\title{
$\pi$ 電子系分子集合体の電子状態と構造の協同性に対するサイズ効果
}

\section{Size Effect on Cooperative Nature between Electronic States and Structures of $\pi$-Conjugated Molecular Aggregates}

\author{
三井 正明 ${ }^{\mathrm{a}}$, 中嶋 敦 ${ }^{\mathrm{a}}$
}

Masaaki Mitsui and Atsushi Nakajima

\begin{abstract}
Supersonically cooled, $\pi$-conjugated molecular cluster anions are efficiently produced up to more than 100 constituent molecules and their electronic states are size-selectively investigated using anion photoelectron spectroscopy. Homogeneous anionic clusters of anthracene, (anthracene) ${ }_{n}^{-}(n=1-100)$, are presented herein as one of noteworthy results among those studies. The coexistence of two types of anionic isomers is found over a broad range in size: isomers I and II-1 $(n=4-30)$ or isomers I and II-2 $(n \geq 40)$. Size-dependent energetics, vibrational features, and temperature variations of photoelectron spectra for each isomer allow us to infer their structural motifs, electron accommodation modes, and formation mechanisms. Such improved knowledge increases our comprehension about size effect on cooperative nature between electronic states and structures of $\pi$-conjugated molecular aggregates at a molecular-level.
\end{abstract}

Keywords: molecular cluster, anion photoelectron spectroscopy, electronic state, structure, $\pi$-conjugated molecule, anthracene

\section{1. はじめに}

分子はファンデルワールスカなどの弱い非共有結合性 相互作用によって凝集し, 液体や固体などの集合状態を形 成する。このような弱い結合では, 隣接した分子間の軌道 の重なりは小さく, 集合した状況下においても分子個々の 構造や性質はほぼ保持されている。ところが, 分子集合体 では分子間相互作用の多体効果に基づく電子状態と集合 構造の「協同」によって, 1 個の分子には見られない新た な性質や機能が発現する。例えば, 生命機能の発現は, 核 酸やタンパク質などの生体分子の集合体において, 電子状 態と構造とが織り成す協同的な現象として捉えられてい る。また近年では, 超分子科学や物性量子化学などの視点 からナノメゾスコピック領域の分子集合系を設計・制御 し, スピンを含めた電子物性と構造の協同効果に基づく新 たな物性・機能を創製しようとする試みが活発に行われて いる。今日，分子集合体におけるこのような協同性を分子 レベルで解明することは, 固体・溶液化学, 物性化学, 表 面・界面科学など多様な分野に遍在した重要な研究テーマ となっている。

気相分子クラスターは, 微視的な分子間に働く相互作用 と巨視的に現れる物性や機能を橋渡しするナノメートル スケールの有限な分子集合体である。分子クラスターでは,

a慶應義塾大学 理工学部 化学科

連絡先 干223-8522 横浜市港北区日吉 3-14-1

電子メール mitsui@sepia.chem.keio.ac.jp

CJapan Society of Molecular Science
1 個の孤立した分子から出発して 2 量体， 3 量体...と 1 個 ずつ集合体を構成する分子数を増やすことができ, 集合体 の構造や性質の変化を構成分子数 (クラスターサイズ) の 関数として調べることができる。よって，このような分子 スケールで精密なボトムアップアプローチから,「どのく らいの数の分子が集合すると集団としての性質が顕在化 しはじめるのか?!,「それはあるサイズから急激に起こる のか?」，「そこに何らかの規則性や法則性があるのか?」 など, 分子集合体の電子状態と構造の協同性に対するサイ ズ効果とその発現機構が明らかになると期待される。

これまで分子クラスターの研究は, 分子線やレーザー光 源などの技術革新, 新しい高感度分光法の開発, 計算機能 力の飛躍的な向上などによって, その研究対象とする分子 系やクラスターサイズを次第に拡大してきた。ところが分 子クラスター研究の主眼が局所的な分子間相互作用の精 密理解にあるため, 水や二酸化炭素などの一部の小型分子 を除いて, 研究対象は分子が 2 数個程度集合した小さな サイズのクラスターに限られてきた。しかしながら, 構成 分子数の増加に伴う物性・機能の発現や種々の物理/化学 現象を分子クラスターにおいて観測し, それらをより体系 的に理解していくためには, 研究対象とする分子系やクラ スターサイズを従来よりも大幅に拡張していくことが必 要である。本稿では, これまであまりクラスターの研究が 進んでこなかった $\pi$ 電子系分子（多環式芳香族炭化水素） に焦点を当て, それらの 100 量体を超える巨大クラスター 
負イオン生成の試みとその光電子分光から見出された $\pi$ 電子系分子集合体の電子構造と集合構造の強い協同性に 基づく電子・幾何構造異性体の共存現象とその発現に対す るサイズ効果および温度効果について紹介する。

\section{2. 巨大な分子クラスターの生成}

弱い非共有結合相互作用を駆動力とする分子クラスタ 一の生成には, 超音速ジェット法を用いるのが有効である。 しかしながら，この方法によって 100 量体を超えるような 巨大サイズの分子クラスターを安定に, かつサイズ選別を 伴った分光法を適用できるほど豊富に生成することは容 易ではない。ここでは, 我々がいかにしてこのようなこと を実現させたかについて述べる。

超音速ジェット法では, 図 1 に示したようにオリフィス 径が 0.1-1 mm 程度のバルブから試料蒸気と希ガス（ヘリ ウムやアルゴンなど) の混合気体を真空中に断熱膨張する ことによってクラスターを生成させる。このとき排気系に かかる負担を大幅に低減するため, 数百 $\mu \mathrm{s}$ 程度のパルス 幅で気体を噴出するのが一般的である。この方法によって できる限り大きなサイズのクラスターを生成させたい場 合には, 試料蒸気圧 $\left(P_{\text {seed }}\right)$ を十分に高くする必要がある。 特に, 昇華性の低い固体試料の場合には, 試料ホルダーな らびにバルブ本体をかなり高温まで加熱しなければなら ない。また生成させるクラスターの冷却具合 (内部エネル ギーまたは温度）を制御するには希ガスの圧力（ $\left(P_{\text {rare }}\right)$ を 幅広く変化させる必要がある。 $P_{\text {seed }}$ を大きな值に保ちなが らシード比 $R=P_{\text {seed }} /\left(P_{\text {seed }}+P_{\text {rare }}\right)$ を小さくする, 即ち $P_{\text {rare }}$ を $P_{\text {seed }}$ よりも十分に大きくすることができれば, 試料 気体と希ガス原子との衝突確率が増大し，よく“冷えた” （内部エネルギーの小さな）巨大クラスターを生成するこ とができる。逆に， $P_{\text {rare }}$ を $P_{\text {seed }}$ と同程度に設定して $R$ 值 を大きくすれば, “温かい”（内部エネルギーの大きな）巨 大クラスターを生成できる。

このようなことを実現可能とするパルスバルブとして, 我々は超短パルス高圧バルブ（Even-Lavie バルブ）にいち 早く着目した ${ }^{1}$ 。このバルブの開閉時間は 約 $20 \mu \mathrm{s}$ と従来 用いられてきたパルスバルブの $1 / 10$ 以下であるため, 非 常に高密度なクラスタービームを生成することができる。

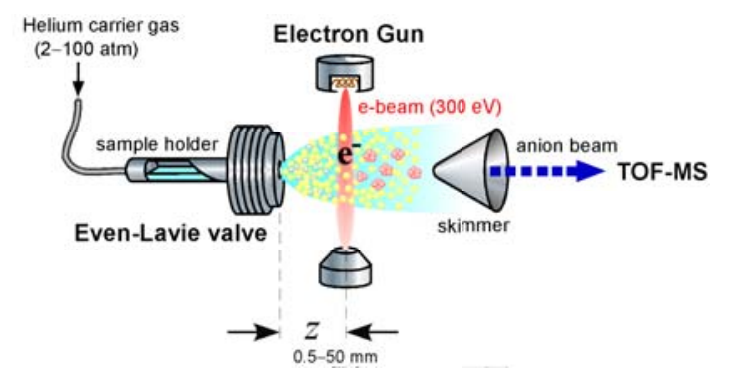

Figure 1. Schematic drawing of an anion production method: high-energy electron impact ionization where the formation of cluster anions results from attachment of slow secondary electrons $(<1 \mathrm{eV})$.

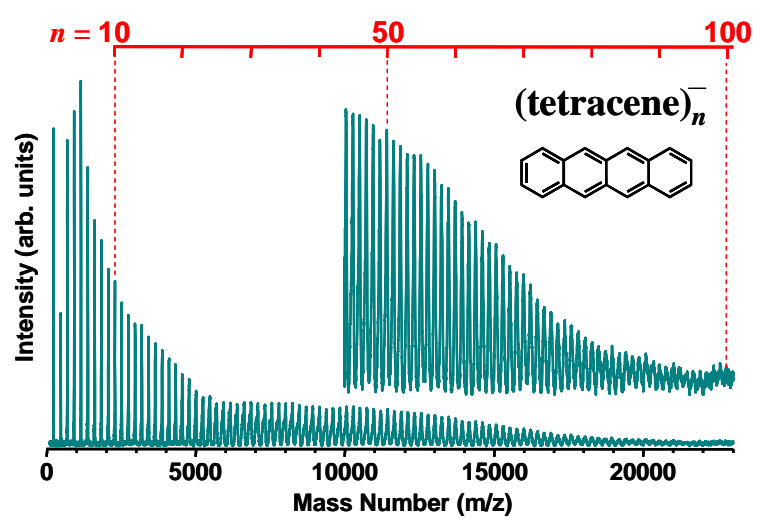

Figure 2. TOF-MS spectrum of tetracene cluster anion.

さらに $0.1 \mathrm{MPa}$ から $10 \mathrm{MPa}$ 以上の高圧下でも安定に駆動 するので，幅広い $R$ 值を実現することができる。これは 前述したように, 単に大きなサイズのクラスターを生成す るということだけでなく, それらの内部エネルギーを様々 に変化させながら生成できるという点で重要である。また 試料ホルダーを含むバルブ本体は $600 \mathrm{~K}$ 付近まで加熱で きるので，不揮発性固体試料についても高い $P_{\text {seed }}$ を実現 でき，巨大クラスターを生成することが可能である。

我々は, Even-Lavie バルブと自作の電子銃を図 1 のよう に組み合わせ, 負電荷を帯びたクラスター (クラスター負 イオン）を生成することを試みた $201-20 \%$ の試料気体を 混入した 0.1-10 MPa のヘリウムガスを Even-Lavie バルブ からパルス的に断熱膨張し，バルブのオリフィスから $Z=$ 1-50 mm 下流で電子線（100-300 eV, 5 mA） と交差させ 電子衝撃イオン化を行った。この電子衝撃イオン化の過程 で発生した低速 2 次電子 $(<1 \mathrm{eV})$ が分子あるいはクラス ターに付着し, その後さらにヘリウムガスとの衝突や分子 蒸発などを繰り返しながら最終的に安定なクラスター負 イオンが生成する。このようにして得た負イオンビームの 一部をパルス電場によって加速し, マイクロチャンネルプ レート ( MCP) 検出器で検出して飛行時間型質量 （TOF-MS）スペクトルを得た。このような生成法により， 我々は様々な有機分子の 100 量体を超える巨大クラスタ 一負イオンの生成に成功してきた ${ }^{2-10}$ 。その一例として, テトラセンクラスター負イオン : (tetracene) ${ }_{n}{ }^{-}$の質量スペ クトルを図 2 に示した。テトラセンは有機固体あるいは有 機半導体の雊形として古くから研究されてきた $\pi$ 電子系 有機固体の一つである。しかしながら, テトラセンの融点 は約 $360^{\circ} \mathrm{C}$ と非常に高く, 小さなクラスターですら生成が 困難であるため, 有機固体の研究とは対照的にクラスター の研究はまったく行われてこなかった。最近, 我々は図 2 のように 100 量体を超える大サイズの (tetracene) ${ }_{n}{ }^{-}$を生成 することに初めて成功した ${ }^{10}$ 。質量の増大とともにクラス ターイオンの飛行速度が次第に減少していくため, 非常に 大きなクラスターに対しては検出器の感度が大幅に低下 する。そのため, 質量スペクトル上では質量数が $25,000 \mathrm{u}$

Page 2 of 8 (page number not for citation purpose) 
（n 110）を超えるクラスターは観測されなかった。しか しながら, 光照射による脱離光電子によって生成分布を測 定したところ, (tetracene) ${ }_{n}^{-}$は質量数 $57,000 \mathrm{u}$ 程度 (約 250 量体）まで生成していることが確認された。この巨大クラ スターの質量数は, 代表的な蛋白質であるへモグロビンの 分子量（約 64,000 u）に匹敵するほどのものである。この ように,これまでクラスターとして研究することができな かった重要な $\pi$ 電子系有機分子群に対して, 巨大クラスタ 一研究の道が切り拓らかれた。

\section{3. 負イオン光電子分光法}

通常の固体や気体の紫外光電子分光 (UPS) では, 中性 状態にある試料を光イオン化するため, 占有準位である価 電子帯 (HOMO; highest occupied molecular orbital など) に 対する情報が得られる。一方, 非占有準位である伝導帯 (LUMO; lowest unoccupied molecular orbital など)について 直接的な情報を得ることは実験的に困難であるため, 有機 固体の LUMO（固体の電子親和力： $E A_{\mathrm{s}}$ ）に関する定量的 な実験データは HOMO に比べ不足している。近年, 逆光 電子分光法 (IPES) などによって分子固体 (薄膜) の LUMO に関する定量的な情報が得られるようになってきた ${ }^{11-14}$ 。 しかしながら, 今のところ IPES のエネルギー分解能は 400-500 meV 程度 ( 4000 $\left.\mathrm{cm}^{-1}\right)$ であるため, 分子振動に 関する情報や高い精度の定量データを得ることが困難で ある。本研究で用いた負イオン光電子分光法では, 図 3 に示したように余剩電子を伴った負イオン状態 $\left(\mathrm{M}^{-}\right)$を 始状態とし, 負イオンから中性状態への光電子脱離過程 $\left(\mathrm{M}^{-} \rightarrow \mathrm{M}+\mathrm{e}^{-}\right)$によって光電子スペクトルを得るため, そ の 0-0 遷移エネルギー（負イオンの振動基底状態 $v=0$ か ら中性の振動基底状態 $v^{\prime}=0$ 一の遷移）から断熱電子脱離 エネルギー $(A D E)$ 即ち分子の断熱電子親和力 $\left(E A_{\mathrm{a}}\right)$ を

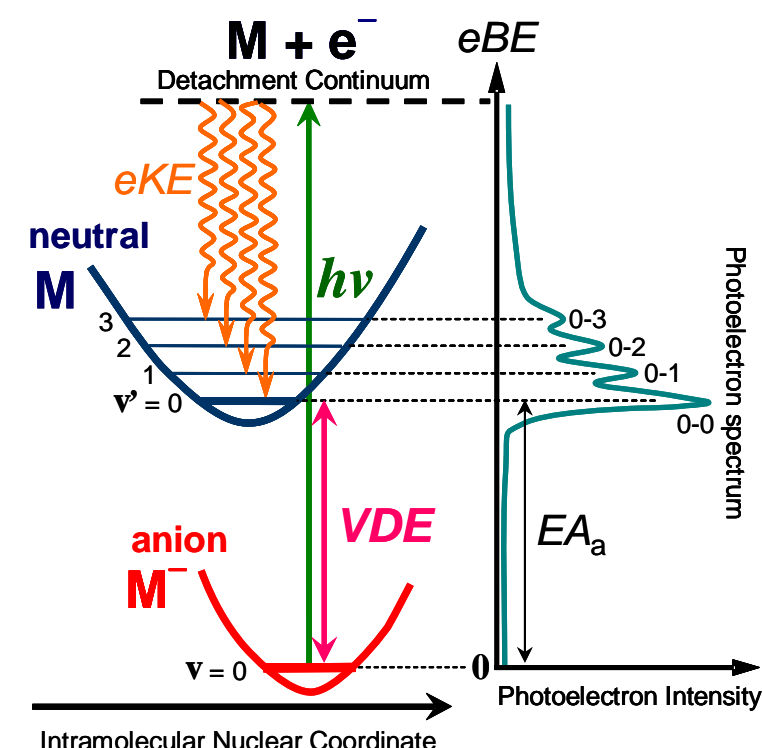

Figure 3. Scheme of the photodetachment transition in anion photoelectron spectroscopy. The right side, the corresponding photoelectron spectrum is displayed. See text for further details.

直接的に決定できる。またスペクトルに振動構造（図中の 0-1, 0-2, 0-3 は, 負イオンの振動基底状態 $v=0$ から中性の 振動励起状態 $v^{\prime}=1,2,3$ 一の遷移を意味する。）が観測さ れれば，電子-振動結合や電子脱離/付着に伴う分子の構造 緩和に関する情報も得ることができる。さらに余剰な電荷 を帯びたクラスター負イオンは飛行時間によって容易に サイズ選別できるので, クラスターサイズ毎の光電子スペ クトルを測定することも可能である。非常に大きなサイズ のクラスターまで光電子スペクトルを測定することがで きれば, 分子が集合していくことによって分子軌道が次第 に固体の電子構造 (バンド構造) に発展していく様子を観 測できると考えられる。

負イオン光電子分光法の基本的な原理は, 通常の光電子

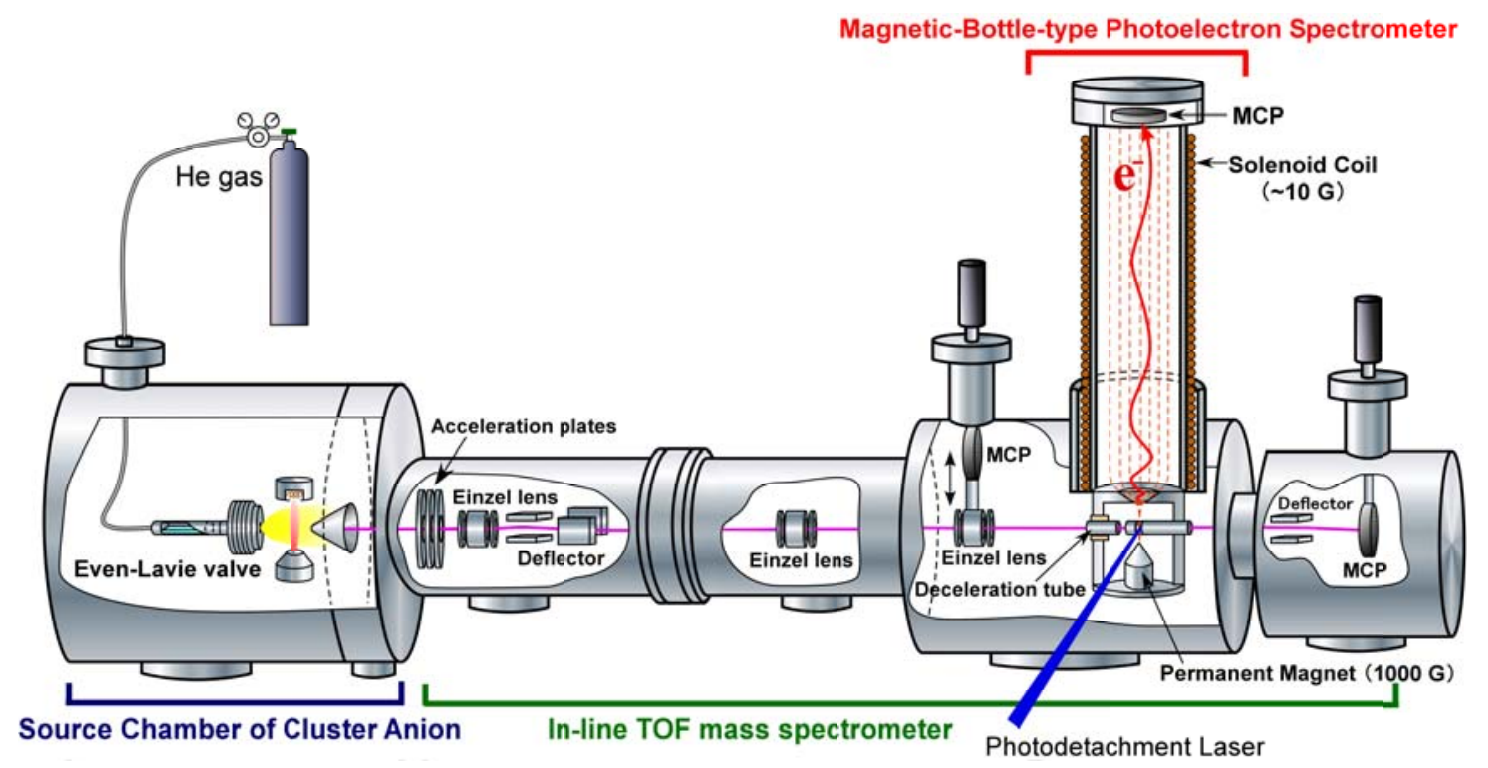

Figure 4. Schematic diagram of our anion photoelectron spectroscopy apparatus with an in-line Wiley-McLaren TOF mass spectrometer and a magnetic-bottle-type photoelectron spectrometer. 


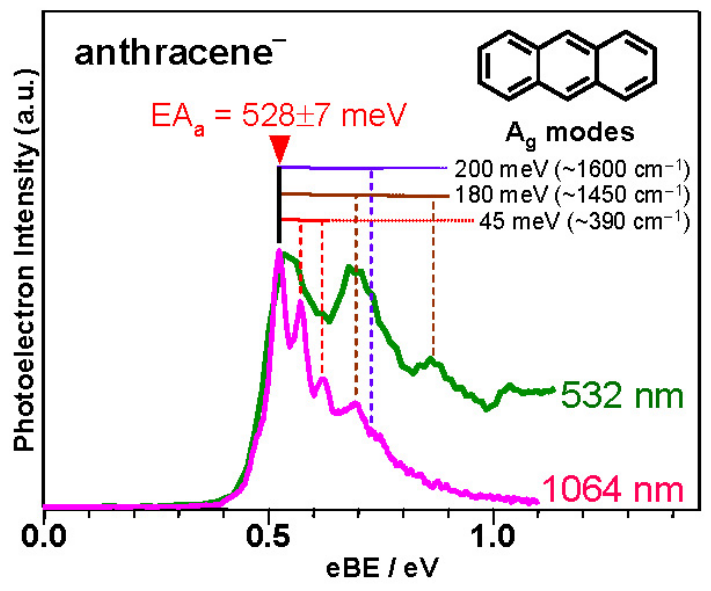

Figure 5. Photoelectron spectra of anthracene molecular anion.

分光法と同様であり, 図 3 に示したように単一のエネルギ 一 $(h v)$ の光を照射することによって分子軌道から放出さ れた電子の運動エネルギー分布 $(e K E)$ を測定する。そし て, クラスターの電子結合エネルギー $(e B E)$ をエネルギ 一保存則に基づく $e B E=h v-e K E$ の関係式から決定する。 図 3 では, 負イオン状態の平衡構造を保持したまま余剩電 子を脱離するのに必要なエネルギー, いわゆる垂直電子脱 離エネルギー（VDE; vertical detachment energy）が $E A_{\mathrm{a}}$ と 一致するように描いてあるが, 弱い分子間力で凝集してい る分子クラスターでは, 負イオン状態と中性状態の平衡構 造が大きく異なる場合が多く, 一般的に $n$ 量体クラスター 負イオンの $\operatorname{VDE}(\operatorname{VDE}(n))$ は，その断熱電子脱離エネル ギー $(A D E(n))$ よりも大きくなる。後述するように $V D E(n)$ と $A D E(n)$ の差 $(\operatorname{VDE}(n)-A D E(n))$ は, 余剩電子脱離に 伴うクラスターの再配向エネルギー $(R E(n))$ に対応して おり, この值が大きいほど電子脱離/付着によるクラスタ 一の構造変化が大きいことになる。このような場合, $A D E(n)$ をスペクトルから求めることは困難であり, 正確 に決定することができる $V D E(n)$ を用いて定量的な議論 がなされることが多い。

我々は前節で述べたクラスター負イオン生成源を図 4 のように磁気ボトル型光電子分析装置に組み込んだ ${ }^{2}$ 。磁 気ボトル型光電子分析器では, 様々な立体角に放出された 光電子のほぼ全てを円錐状の永久磁石が作り出す強力な 不均一磁場によって弱磁場方向一跳㱛返し, 光電子飛行管 に巻かれたソレノイドコイルによる均一磁場によって検 出器まで導く。その飛行時間により運動エネルギーの異な る電子は空間的に分離され, 光電子の運動エネルギー分布 を測定することができる。光電子飛行管が長いほど光電子 の空閒的な分離が進行するので, エネルギー分解能が向上 する。通常の磁気ボトル型光電子分析器のエネルギー分解 能は, $1 \mathrm{eV}$ の運動エネルギーをもつ電子に対して 25-70meV (200-600 $\left.\mathrm{cm}^{-1}\right)$ 程度であり, 分子振動を分離

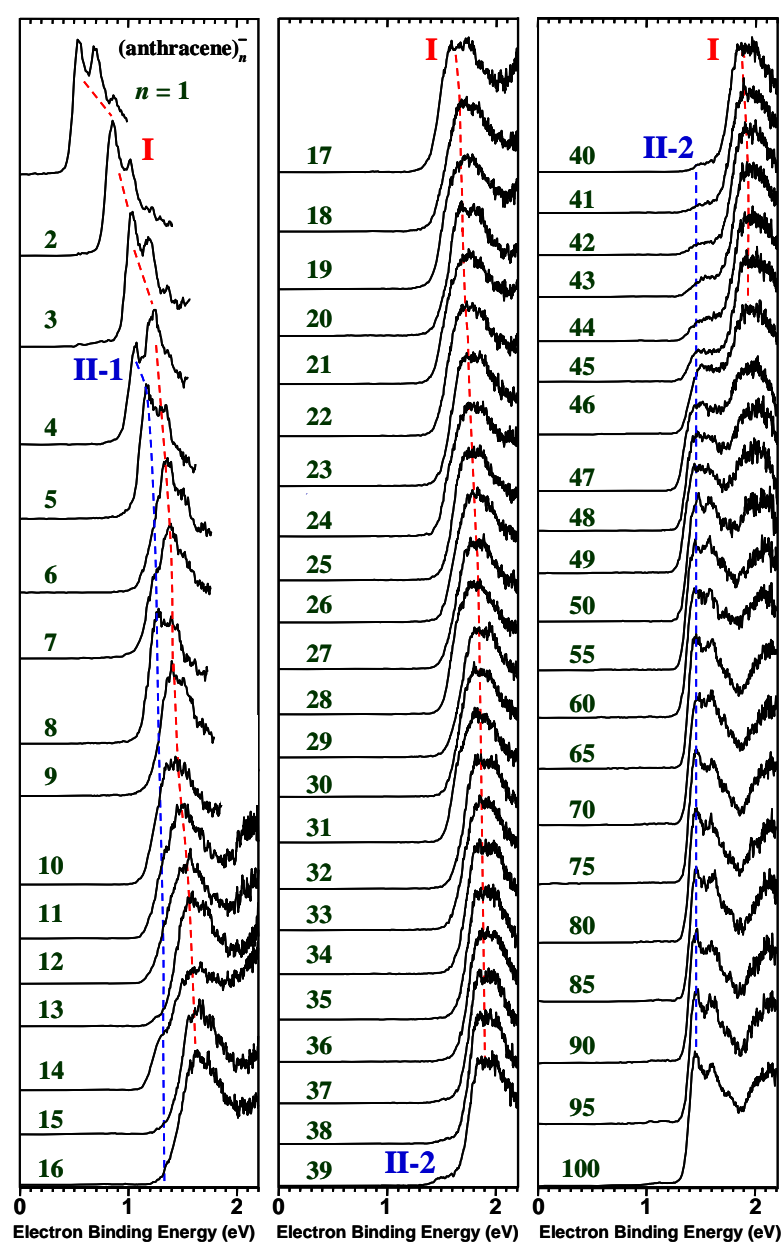

Figure 6. Photoelectron spectra of (anthracene) $)_{n}^{-}(n=1-100)$, recorded for a later fraction of the anion beam at helium stagnation pressure of 4.9 MPa. Bands labeled by I, II-1, and II-2 are arisen from different anionic isomers. See text for further discussion.

して観測することが可能である。ここでは，実際の測定例 として $1064 \mathrm{~nm}(1.165 \mathrm{eV})$ および $532 \mathrm{~nm}(2.331 \mathrm{eV})$ を 脱離レーザー光に用いて測定したアントラセン分子負イ オン (anthracene ${ }^{-}$) の光電子スペクトルを図 5 に示した。 脱離光電子の運動エネルギーを抑えることによって振動 構造が分離された良質なスペクトルが得られ, アントラセ ン分子の $E A_{\mathrm{a}}$ が $528 \pm 7 \mathrm{meV}$ と高い精度で決定された。ま た観測されている振動構造は C-C 伸縮振動などの $\mathrm{A}_{\mathrm{g}}$ モー ドに帰属され ${ }^{15,16}$, これらの振動モードにおいて強い電子 -振動結合があることが分かる。

\section{4. $\pi$ 電子系分子クラスターの電子状態と構造の協同}

一般的に $\sigma$ 電子しか持たない分子（例えばアルカンな ど）で構成される固体は， $\sigma$ 軌道の空間的な広がりが小さ いため分子間の軌道の重なりがほとんどなく絶縁体であ る。これに対して $\pi$ 軌道は分子の外側に大きく広がってお り分子間で比較的大きな重なりをもつ。したがって， $\pi$ 電 子系分子固体は, いわゆる有機半導体あるいは有機電導体 としてこれまで膨大な数の研究が行われてきた。特に近年 では，分子のパッキング様式（分子間距離や配向など）に

Page 4 of 8 (page number not for citation purpose) 


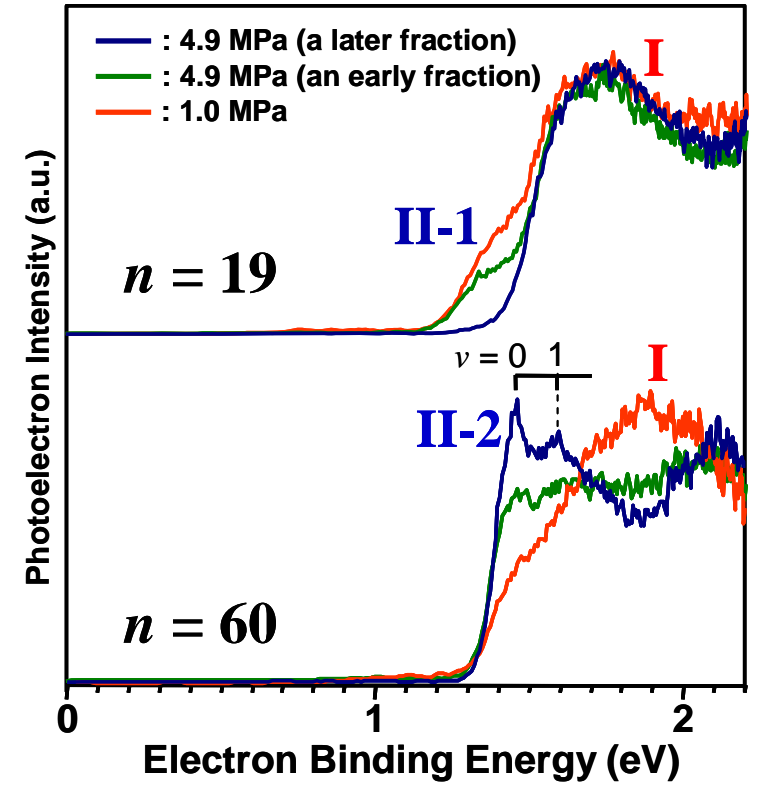

Figure 7. Cluster formation condition effects on photoelectron spectra of (anthracene) ${ }_{n}^{-}$with $n=19$ and 60. See text for further discussion.

よって HOMO/LUMO 準位の位置や電荷キャリアの空間分 布 (バンド幅) が顕著に変化すること ${ }^{17-19}$ や温度によって バンド幅が変化したり, 構造の熱摇らぎによって電荷が局 在化したり寸ることが示されている ${ }^{20-22}$ 。これらは有機半 導体の電荷輸送機構に関わる重要な基礎的問題として, 現 在も活発に研究が進められている。ここでは, 最も基本的 な $\pi$ 電子系分子固体の一つとして古くから研究されてき たアントラセンのクラスター負イオン: (anthracene) ${ }_{n}{ }^{-}(n=$ 1-100) の光電子分光の結果を例に, このような $\pi$ 電子系 分子固体の電子構造と集合構造における協同性とそれに 対する温度効果が, 有限な分子集合系においてどのように 現れるかについて見ていく。

4.1. 光電子スペクトル

図 6 に $532 \mathrm{~nm}(2.331 \mathrm{eV})$ を脱離レーザー光に用いて測 定した (anthracene $)_{n}{ }^{-}(n=1-100)$ の光電子スペクトルを 示す。すべてのスペクトルは, クラスター生成時のヘリウ ムガス圧を $4.9 \mathrm{MPa}$ の高圧に設定して測定したものであ る。スペクトルの変遷を小さなサイズから順に見ていくと， まず $n=1$ から 3 で振動構造を伴ったピークが大きく高エ ネルギー側にシフトし，LUMO 準位がサイズとともに大 きく安定化していることが分かる。このピークを以後 “ピ 一ク I”と呼ぶ。ところが $n=4$ では，ピーク I の低エネル ギー側に新たなピーク “II-1”が観測され, 以降 14 量体付 近までピーク I と II-1の寄与が混在した不規則なスペクト ル形状が観測された。また図 6 の測定条件では, 15 量体 以降でピーク I の低エネルギー側にピーク II-1 がまったく 観測されていないが，ヘリウムが $1 \mathrm{MPa}$ 以下の低圧条件 では 30 量体付近まで弱く観測されることが分かっている。 40 量体を超えるサイズ領域になると, ピーク I の低エネ ルギー側に新たなピーク “II-2”が現れ，その強度がサイ
ズとともに急激に増大する挙動が観測された。興味深い事 にピーク II-2 は，ピーク II-1 $(n \geq 14)$ よりも $0.1 \mathrm{eV}$ 程度 高エネルギー側に現れており, サイズが 100 量体まで増加 してもピーク II-2 はまったくシフトしていない。さらにピ ーク II-2 には，分子負イオンで見られた C-C 伸縮振動に 由来した振動構造が観測されていることが分かる。

図 7 に示すように, ピーク I と II-1 およびピーク I と II-2 の相対強度はクラスター生成条件やクラスタービームを 加速する (引き出す) タイミングによって大きく変化した。 特にピーク II-2 は, $P_{\text {rare }}$ を $1 \mathrm{MPa}$ 以下に設定してクラスタ 一の冷却効果を抑えた場合にはほとんど観測されず, ピー ク I が強く観測された。逆に $P_{\text {rare }} \geq 4 \mathrm{MPa}$ の高圧下で生成 したクラスタービームの後半部分, 即ち希ガス原子との非 弾性衝突をより多く経験することによって “より冷えた” クラスター負イオンに対してスペクトルを測定すると, ピ 一ク II-2 がより強く観測され, 同時に振動構造も明瞭に観 測されることが分かった。この結果は，ピーク II-2 を与え るクラスター負イオン状態の生成が, クラスターサイズだ けでなくクラスターの内部エネルギー（温度）にも強く依 存していることを示している。

以上の結果から, (anthracene) ${ }_{n}^{-}$では $n=4-30$ において二 つの電子束縛状態の異なる異性体 I と II-1 が， $n \geq 40$ では 異性体 I と II-2 が共存していることが明らかとなった。以 下では, それぞれの異性体がどのようなものであるかにつ いて考察していく。

\section{2. 電子状態に関する考察 : $-\operatorname{VDE}(n)$ vs $n^{-1 / 3}$ プロット}

(anthracene) $)_{n}$ における各異性体の “ $V D E(n)$ ”の值を $\tilde{n}^{1 / 3}$ に 対してプロットしたものを図 8 に示す。( $n^{1 / 3}$ はクラスター を半径 $R$ の球体と仮定した際の $\tilde{R}^{1}$ に比例した量である。） 図中の左側 $(n=\infty)$ には, $\operatorname{Ag}(111)$ 表面上のアントラセン 固体薄膜の IPES から決定された“真空準位からの LUMO 準位のエネルギー” $(1.7 \mathrm{eV})$ を示した ${ }^{11}$ 。また図中の点線 (緑色) は, アントラセン単結晶中の 1 分子の LUMO に余 剰電子が局在化していると仮定し, その分子負イオン $\left(E A_{\mathrm{a}}\right.$ $=0.53 \mathrm{eV})$ が, そこから半径 $R$ の範囲内に存在する $n$ 個 の中性分子によってどれだけ安定化を受けるか (即ち, 分 極エネルギー: $\dot{P}(n))$ を分子間の軌道の重なりを無視した 理論モデル (zero-overlap モデル) によって求め, $n^{1 / 3}$ に対 してプロットしたものである ${ }^{23}$ 。

図 8 から, 異性体 I $の-\operatorname{VDE}(n)$ が $n=7$ 付近 $\left(n^{-1 / 3} \sim 0.52\right)$ から $n^{-1 / 3}$ に対してほぼ直線的に増加していることが分か る。これは, 例えば $\mathrm{I}^{-}(\mathrm{Xe})_{n}$ や $\mathrm{Br}^{-}\left(\mathrm{CH}_{3} \mathrm{CN}\right)_{n}$ などの余剰電 荷が強く局在化した溶媒和型クラスターにおいて見られ る一般的な挙動であり ${ }^{24,25}$, 新たな溶媒 1 分子が付着した ことによる負イオン状態の安定化が中性状態のそれより も大きく, さらにその安定化が 3 次元的な溶媒和殼の成長 とともに一様に進行することに起因している。よって異性 体 I では, 余剩電子はアントラセン 1 分子に強く局在化し 


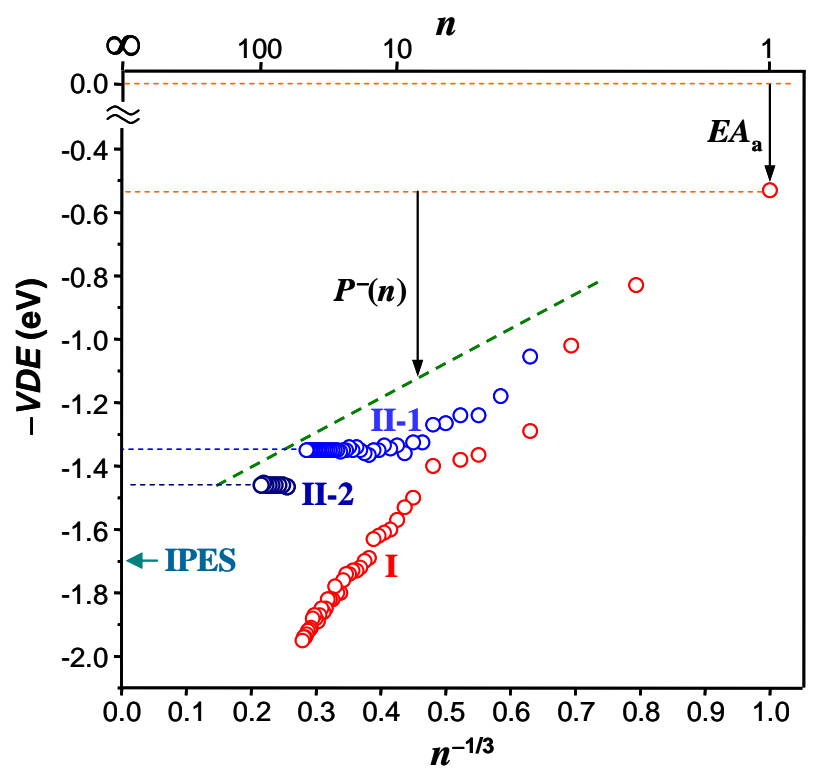

Figure 8. Plot of $-V D E$ of isomers I, II-1, and II-2 as a function of $n^{-1 / 3}$ $E A_{a}$ and $P^{-}(n)$ represent molecular adiabatic electron affinity and polarization energy, respectively. See text for further discussion.

ており，その単量体負イオン (anthracene ${ }^{-}$) の周囲に（恐 らく 3 次元的に) 配位した中性のアントラセン分子が分極 することによって anthracene-が安定化されていると考え られる。しかしながら, 異性体 I の $-V D E(n)$ の值とその プロットの傾きが zero-overlap モデルの結果（緑点線）よ りもかなり大きいことから, 異性体 I の $-V D E(n)$ 值は, $-E A_{a}$ と分極エネルギー $\left(P^{-}(n)\right)$ の和（即ち $\left.-A D E(n)\right)$ の寄与 以外に余剩電子脱離に伴うクラスターの再配向エネルギ 一 $(R E(n))$ の寄与 (図 9 参照) を次式のように含んでい ることが分かる。

$-V D E(n)=-E A_{\mathrm{a}}+P^{-}(n)-R E(n)=-A D E(n)-R E(n) \quad(1)$

一方, 異性体 II-1 ( $n \geq \sim 12)$ 抢よび異性体 II-2 $(n=40-100)$ の-VDE $(n)$ 值はサイズにまったく依存せず，それぞれ $-1.35 \mathrm{eV}$ および $-1.47 \mathrm{eV}$ のまま一定であった。これはサ イズ増加に伴う中性状態と負イオン状態の安定化がほぼ 同程度であることを意味しており, 余剩電子が 1 分子に局 在化していると仮定した zero-overlap モデルでは説明する ことができない挙動である。一般に, 分極による安定化は, 電荷の空間分布が広がるほど小さくなるため, これらの異 性体では, 余剩電子の非局在化によってサイズ依存性が消 失したと考えられる。ただし先に述べたように，ピーク II-2 にはアントラセン分子の C-C 伸縮振動モードに由来し た振動構造が明瞭に観測されていることから, 余剩電子の 非局在化の程度は小さく, 2 数分子程度のものと予想され る ${ }^{6,10}$ 。また異性体 II-2 の -VDE $(n)$ 值 $(-1.47 \mathrm{eV})$ が, zero-overlap モデルの $n=\infty$ の值 $(-1.6 \mathrm{eV})$ と比較的良い 一致を示しているが, 本研究の結果は, 分極による安定化 だけでなく電荷共鳴相互作用の寄与 (バンド幅) も考慮し た理論モデルによって LUMO 準位のエネルギーを評価す る必要があることを示唆している。一方, IPES の值
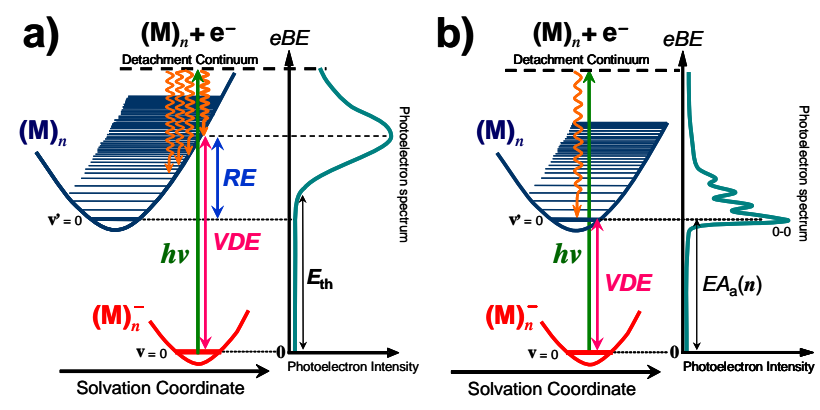

Figure 9. Schematic diagrams of the photodetachment transition in anion photoelectron spectroscopy. See text for further details.

$(-1.7 \mathrm{eV})$ は, 異性体 II-2 の值よりも $0.2 \mathrm{eV}$ 程度大きな値 であるが，IPES の結果は 2-3 層程度のアントラセン固体 薄膜に対して得られたものであり,そのような薄膜では金 属基板の鏡像電荷の影響によりバルク固体よりも LUMO 淮位が 0.2-0.3 eV 程度安定化することが明らかにされて いる ${ }^{13}$ 。よって, 異性体 III-2の一定な $-\operatorname{VDE}(n)$ 值 $(-1.47 \mathrm{eV})$ は，実質的にアントラセン固体の LUMO 準位のエネルギ 一 $\left(E A_{\mathrm{s}}\right)$ にほぼ一致していると考えられる。

このようにたった 50 分子程度で, バルク固体に匹敵す るほど余剩電荷が安定化されることは大きな驚きであり, これは余剩電荷に対する分極が空間的に非常に局在化し ていることを明確に示している。今のところ電荷共鳴エネ ルギーと分極エネルギーがどのような割合で余剩電子の 安定化に寄与しているか明らかではないが，この結果は， 有機固体の電荷キャリア局在状態（ポーラロン）と密接に 関連していると考えられ，巨大クラスターの研究を通じて 得られた分子レベルの新しい知見である。

\section{3. 生成機構と集合構造に関する考察}

図9(a)（略号については3.を参照）に示したように負イ オン状態と中性状態のクラスターの平衡構造が大きく異 なると, $R E(n)$ の寄与により $V D E(n)$ はピークの立ち上が りのエネルギー $\left(E_{\mathrm{th}}\right)$ よりもかなり大きくなる。さらに エネルギー的に近接した多数の低波数分子間振動モード が光電子脱離過程で励起されるため振動構造のないブロ ードなピーク形状が観測される。これらはピーク I の特徽 (図 6,7) とよく対応しており, 異性体 I は, 電子付着によ り中性クラスターの構造から大きく構造緩和した負イオ ン状態であることが分かる。異性体 Iの生成機構としては, 負イオン分子に中性分子が次々と凝集するボトムアップ 的な生成過程が考えられるが, 異性体 I がクラスターの冷 却効果を抑えた“温かい” 条件で生成しやすいことから， 比較的大きな内部エネルギーをもった “液体的な” 中性ク ラスターに電子付着が起こり, 負イオン分子周辺の中性分 子が再配向することによって生成する過程も競合してい るのではないかと推測される。

一方, ピーク II-1 と II-2 は, ピーク I よりも $E_{\mathrm{th}}$ と VDE $(n)$ の差, 即ち $R E(n)$ が非常に小さく, 特にピーク II-2 では 振動構造を伴ったプロファイルが観測されている(図 7)。 


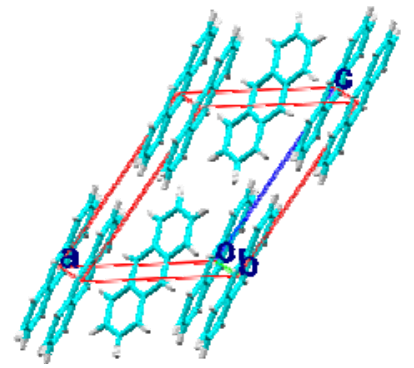

Figure 10. Crystalline structure of solid anthracene.
これは図 9(b)に示した負 イオン状態と中性状態の 平衡構造が類似している 場合に対応する。一般に アントラセンなどの構造 異方性の高い $\pi$ 電子系分 子は, 分子間相互作用に 強い異方性があり，それ らの結晶（例えば図 10）

は $\pi-\pi$ 相互作用の大きい a-b 面（ヘリングボーン層）平 行方向に成長しやすい。実際, 小さな中性アントラセンク ラスターの場合でも，ヘリングボーン的なパッキングの 2 次元集合構造が安定であることが理論的に示されている 26。よって, 小さなサイズ領域で現れる異性体 II-1 は, 図 11 に模式的に示したような中性状態の 2 次元集合構造形 態を保持したまま生成したクラスター負イオンと考えら れる。このようなへリングボーン層では分子間の $\pi$ 軌道の 重なり（移動積分）が比較的大きく, オリゴアセン系結晶 のバンド計算から LUMO のバンド幅が数百 $\mathrm{meV}$ 程度に 及ぶことが示唆されている ${ }^{27}$ 。このとは異性体 II-1 にお いて余剰電子の弱い非局在化が起こっているという先に 与えた解釈と矛盾しない。また, 異性体 II-1 はV VDE (n) が 一定になる $n=14$ 付近から生成しにくくなり, 特に $n=$ 15-30 では，“温かい” 生成条件のときにのみ弱く生成す ることから, サイズが大きくなるにつれて異性体 I よりも エネルギー的に不安定な状態になっていることが分かる。 これは 2 次元集合構造の異性体 II-1 では，（弱く非局在化 した）余剩電荷の安定化が負イオン周囲の閉殼構造形成と それに伴う電荷の遮蔽によってすぐに飽和してしまうの に対し ${ }^{10}$ ，余剰電子が 1 分子に局在化した異性体 I では, 40 量体を超える大きなサイズまで 3 次元的な分極安定化 が進行するためである。

一方, 40 量体以上の大きなサイズ領域において現れる 異性体 II-2 は，異性体 II-1 よりも $0.12 \mathrm{eV}$ 大きい一定の $-V D E(n)$ 值 $(-1.47 \mathrm{eV})$ をもち, 前述したようにその值は バルクの值 $\left(E A_{\mathrm{s}}\right)$ に対応している。よって異性体 II-2 は, 異性体 II-1 が多層化してより結晶の構造形態に近づいた 集合体（図 11 右）ではないかと推測される。異性体 II-2 がクラスターをよく冷却したときにのみ生成することか ら, 内部エネルギーが小さい “結晶的な” 中性クラスター に電子付着が起こると, その構造をほぼ保持したまま負イ オン状態に遷移することが分かる。これはオリゴアセン系 結晶の局在電荷に対する格子緩和エネルギーが $10 \mathrm{meV}$ 程 度と非常に小さく, 結晶格子が “固い”ことと類似してい る ${ }^{28}$ 。また, 結晶のヘリングボーン層 ( $\mathrm{a}-\mathrm{b}$ 面) 内では電 子移動度が特に大きいことから ${ }^{29}$, 異性体 II-2 (および II-1) の生成過程では, 余剩電子が分子間の電子移動 (ホッピン グ)によって最も安定化されるクラスター内部まで速やか

\section{Isomer II-2}
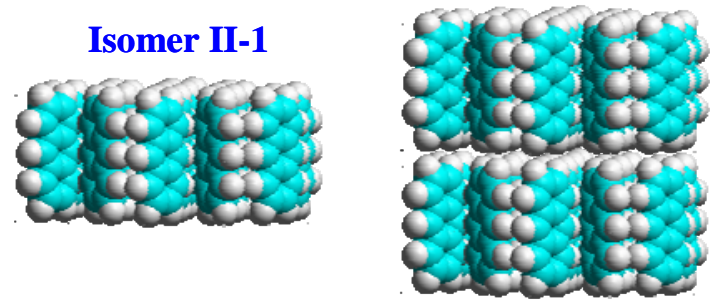

Figure 11. Proposed structural motifs of isomers II-1 and II-2

に移動し，そのため大きな構造緩和（再配向）が起こらな かった可能性も考えられる。このような負イオン状態の生 成機構は $\pi$ 電子系分子結晶の電子伝導機構と強い関わり をもっていることが予想され, 今後, 理論的に検証すべき 興味深い問題である。

\section{5. おわりに}

本稿では， $\pi$ 電子系分子の巨大クラスターの生成とその 負イオン光電子分光をアントラセンの結果を中心に紹介 した。特に 40-50 量体のサイズ領域から， $\pi$ 電子系分子ク ラスターにおける余利電子の局在性とその構造形態が強 く相関していることを示す「電子・幾何構造異性体の共存 現象」が, サイズ増加に伴う電子状態の変遷を追跡するこ とによって見出された。さらに興味深いことに，この共存 現象はクラスターサイズのみならずクラスターの内部エ ネルギー（温度）にも極めて敏感であり，これらの依存性 は有機固体のバンド幅が温度によって大きく変化するこ とを彷彿とさせる ${ }^{20-22}$ 。しかしながら, クラスターの構造 や余利電子の局在化の程度, さらにそれらに対する内部エ ネルギーの影響については, 今のところ定性的な理解にと どまっている。あいにく現時点では, 本研究で対象とした ような大サイズの $\pi$ 電子系分子クラスターの集合構造を 決定する有力な方法がなく, 今後, 動的な集合構造転移の 観測も視野に入れた新たな実験的アプローチが必要であ る。またこのような大自由度系の実験結果をモデル化する ための理論的な取り組みもこれからの挑戦的な課題であ り, 特に分極効果と電荷共鳴相互作用の競合を正しく評価 できる信頼性の高い第一原理的な分子動力学法が適用さ れることが望まれる。いずれにしても, 巨大サイズの分子 クラスターに対する詳細な研究はまだ端緒についたばか りであり，今後乗り越えなければならない壁も多いが，こ のような分子レベルの研究を進めていくことによって, 分 子集合体の電子状態と構造の協同性が, サイズ依存性を含 めて一層深く理解されていくことが期待される。

本研究は, 慶應義塾大学大学院生, 安藤直人君, 小久保慎介君, 松本由生乃さんとの共同研究であり, この場を借りて深く感謝い たします。 


\section{引用文献}

(1) Even, U.; Jortner, J.; Noy, D.; Lavie, N.; Cossart-Magos, C. J. Chem. Phys. 2000, 112, 8068-8071.

(2) Mitsui, M.; Nakajima, A.; Kaya, K.; Even, U. J. Chem. Phys. 2001, 115, 5707-5710.

(3) Mitsui, M.; Nakajima, A.; Kaya, K. J. Chem. Phys. 2002, 117, 9740-9749.

(4) Mitsui, M.; Ando, N.; Kokubo, S.; Nakajima, A.; Kaya, K. Phys. Rev. Lett. 2003, 91, 153002.

(5) Mitsui, M.; Kokubo, S.; Ando, N.; Matsumoto, Y.; Nakajima, A.; Kaya, K. J. Chem. Phys. 2004, 121, 7553-7556.

(6) Ando, N.; Kokubo, S.; Mitsui, M.; Nakajima, A. Chem. Phys. Lett. 2004, 389, 279-283.

(7) Mitsui, M.; Matsumoto, Y.; Ando, N.; Nakajima, A. Eur. Phys. J. D 2005, 34, 169-172.

(8) Mitsui, M.; Matsumoto, Y.; Ando, N.; Nakajima, A. Chem. Lett. 2005, 34, 1244-1245.

(9) Mitsui, M.; Nakajima, A. Bull. Chem. Soc. Jpn. 2007, in press

(10) Mitsui, M.; Ando, N.; Nakajima, A. submitted

(11) Frank, K. H.; Yannoulis, P. Dudde, R.; Koch, E. E. J. Chem. Phys. 1988, 89, 7569-7576.

(12) Hill, I. G.; Kahn, A.; Soos, Z. G.; Pascal, Jr., R. A. Chem. Lett. 2000, 327, 181-188.

(13) Amy, F.; Chan, Chan, C.; Kahn, A. Org. Elect. 2005, 6, 85-91.

(14) Seki, K.; Kanai, K. Mol. Cryst. Liq. Cryst. 2006, 455, 145-181.
(15) Schiedt, J.; Weinkauf, R. Chem. Phys. Lett. 1997, 266, 201-205.

(16) Kato, T.; Yamabe, T. J. Chem. Phys. 2001, 115, 8592-8602.

(17) Sato, N.; Seki, K.; Inokuchi, H.; Harada, Y. Chem. Phys. 1986, 109, 157-162.

(18) Deng, W. Q.; Goddard III W. A. J. Phys. Chem. B 2004, 108, 8614-8621.

(19) Fukagawa, H.; Yamane, H.; Kataoka, T.; Kera, S.; Nakamura, M.; Kudo, K.; Ueno, N. Phys. Rev. B 2006, 73, 245310.

(20) Hannewald, K.; Stojanović, V. M.; Schellekens, M. T.; Bobbert, P. A.; Kresse, G.; Hafner, J. Phys. Rev. B 2004, 69, 075211.

(21) Koch, N.; Vollmer, A.; Salzmann, I.; Nickel, B.; Weiss, H.; Rabe, J.P. Phys. Rev. Lett. 2006, 96, 156803.

(22) Troisi, A.; Orlandi, G. Phys. Rev. Lett. 2006, 96, 086601.

(23) Tsiper, E. V.; Soos, Z. G. Phys. Rev. B 2001, 64, 195124.

(24) Becker, I.; Cheshnovsky, O. J. Chem. Phys. 1999, 110, 6288-6297.

(25) Markovich, G.; Perera, L.; Berkowitz, M. L.; Cheshnovsky, O. J. Chem. Phys. 1996, 105, 2675-2685.

(26) Piuzzi, F.; Dimicoli, I.; Mons, M.; Millié, P.; Brenner, V. Zhao, Q.; Soep, B.; Tramer, A. Chem. Phys. 2002, 275, 123-147.

(27) Cheng, Y. C.; Silbey, R. J.; da Silva Filho, D. A.; Calbert, J. P.; Cornil, J.; Brédas, J. L. J. Chem. Phys. 2003, 118, 3764-3774.

(28) Brovchenko, I.V. Chem. Phys. Lett. 1997, 278, 355-359.

(29) Witte, G.; Wöll, C. J. Mater. Res. 2004, 19, 1889-1916.

（受理日 2007 年 6 月 1 日）

三井正明氏は, 2005 年の分子構造総合討論会（東京）における研究発表，「気相分子クラスターにおける固体-液体類似相の共存」な どの業績によって奨励賞を受賞され, 翌 2006 年の分子構造総合討論会（静岡）において奨励賞招待講演「負イオン光電子分光法に よる有機半導体クラスターの電子構造の系統的研究」を行われました。本稿は, その研究内容の解説です。

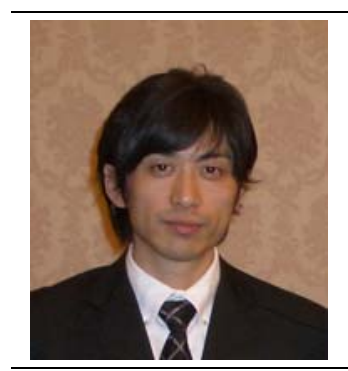

三井正明（みついまさあき）

所属 : 慶應義塾大学理工学部化学科

専門分野: 物理化学, クラスター科学

連絡先：干223-8522 横浜市港北区日吉 3-14-1

電子メール : mitsui@sepia.chem.keio.ac.jp, URL : http://sepia.chem.keio.ac.jp/Nakalab/

中嶋敦（なかじまあつし）

所属 : 慶應義塾大学理工学部化学科

専門分野: 物理化学, クラスター科学

連絡先 : $=223-8522$ 横浜市港北区日吉 3-14-1

電子メール : nakajima@chem.keio.ac.jp, URL : http://sepia.chem.keio.ac.jp/Nakalab/ 